\title{
Evaluation of Street Food Vending in Ozamiz City
}

\author{
Nelfa D. Canini ${ }^{1}$, Jessie Jane O. Bala ${ }^{2}$, Evangeline N. Maraginot ${ }^{2}$, \\ Bebs Catherine B. Mediana ${ }^{3}$ \\ ${ }^{1}$ Department of Biological Sciences, College of Education, Misamis University, \\ Ozamiz City, Philippines \\ ${ }^{1-2}$ Natural Science Department, College of Arts \& Sciences, Misamis University, \\ Ozamiz City, Philippines \\ ${ }^{3}$ College of Medical Technology, Misamis University, Ozamiz City, Philippines \\ Corresponding email: neldum_can@yahoo.com
}

\begin{abstract}
Food security in terms of adequate quantity and quality of food to lead a healthy life must be considered as the prime function of a food system. This study aimed to investigate the microbial quality of street-vended foods and the factors predisposing to their contamination. Interviews were conducted using a pre-tested questionnaire to collect data from 110 street vendors on their profile and hygiene practices. Standard methods were used for the enumeration of total bacterial counts and identification of Staphylococcus aureus and Escherichia coli. Examinations were made of 173 menu items, classified as snack foods, main dishes, sauces, and cold dishes. The microbial quality of most of the foods was within the acceptable limits (less than 5.0 $\log _{10} \mathrm{cfu} / \mathrm{g}$ ), but samples of buko juices, fruit salads, burger bun with spaghetti, and pansit with pork had unacceptable levels of contamination with a total mean $\log _{10} \mathrm{cfu} / \mathrm{g}$ of $7.1,7.0,6.1$, and 6.0 respectively. $S$. aureus was detected in 104 food samples (60.1\%) and 69 contained E. coli $(39.9 \%)$. Time and temperature abuse, exposure of food to flies, and poor hygiene practices during preparation and serving were likely the risk factors for contamination. Vendors have to receive education and training on food hygiene to improve the safety of street foods in Ozamiz City and thereby heighten the safety of consumer.
\end{abstract}

Keywords: bacteria, food contamination, food handling, food services, risk factors 


\section{Introduction}

Foodborne illness is a major international health problem which influences an estimated $30 \%$ of individuals annually (Powell, 2010). Meals prepared outside of the home are a risk factor for obtaining foodborne illness and have been implicated in up to $70 \%$ of traced outbreaks. The problems of food safety in the industrialized world differ considerably from those faced by developing countries. Whereas traditional methods are used for marketing fresh produced in the latter countries, food processing and packaging are the norm in industrialized countries. In developing countries, a large proportion of ready-to-eat food is sold on the streets (Faruque et al., 2010).

The Food and Agricultural Organization (FAO) defines street food as a wide range of ready-to-eat foods and beverages prepared and/or sold by mobile or stationary vendors and hawkers especially on streets and around public places (Dardano, 2003; Nirathon, 2006; Faruque et al., 2010; Cho et al., 2011; Monsterjc, 2013). Such foods feed millions of people daily with a wide variety of foods that are relatively cheap and easily accessible. In selling snacks, complete meals, and refreshments at relatively low prices, vendors provide an essential service to students, workers, shoppers, travelers, and people on low income (Rheinländer et al., 2008). People who depend on such food are often more interested in its convenience than in questions of its safety, quality and hygiene. However, the World Health Organization (WHO) undertook a survey in over 100 countries to assess the situation with regard to street-vended foods. The survey noted that majority of countries reported contamination of food that contributes to food-borne disease (Donkor, 2009; Bhowmik, 2005). This was partly due to the fact that infrastructure development was relatively limited, with restricted access to potable water, toilets, refrigeration and washing and waste disposal facilities (Muzaffar, 2009). Moreover, registration, training and medical examinations were not among the selected management strategies (Martins, 2006). One of the frequent problems in the sale of street foods is their actual and potential hazard caused by bacterial contamination (Muñoz de Chávez et al., 2000). The Caribbean Epidemiology Centre (CAREC, 2002) reported that there were 2597 reported cases of foodborne illness in 2000 and 1905 cases in 2001. The Centers for Disease Control (CDC), 
Atlanta has estimated that about one-third of the inhabitants in the United States acquire a food borne disease annually (Griffiths, 2002). A rise in notified cases of food poisoning has occurred across most of Europe and North America; in particular, in the incidence of microbial food poisoning of animal origin (Miles et al.,1999). Over 2 million cases of foodborne diseases occur in Canada each year, many of the cases consist of mild symptoms and are often mistaken for the 'stomach flu' (Halton Regional Health Department, 2001).

Urbanization has resulted in proliferation of street food vendors and hawkers as the movement of people from rural to urban areas has led to the need to feed large numbers of working people away from their place of residence. With the increasing pace of urbanization in Ozamiz City, street food vending is a popular type and distinctive part of a large informal sector providing the vendors with a means to sustain their livelihood. It is commonly viewed in public places particularly in busy streets. The most common street foods in Ozamiz city include fishballs, tempura, barbecued pork, pig's blood or dried chicken blood (colloquially, Betamax after its rectangular shape resembling the Betamax tape), chicken heads (helmet), chicken feet (adidas) (List of street foods, 2013), ( chicken intestines (isaw), taho (a type of soft beancurd served with syrup), burgers, fruit salad, coconut milk drink (buko juice), hotdogs and hot cakes.

While the importance of street-vended food is not to be negated as an important source of nourishment as well as income and work opportunity offered for the informal sector, the safety of the food is a particular problem, especially from a microbiological point of view. Investigating the profile of street food vendors, hygiene practices as well as the microbial quality of street-vended foods are vital to ensure consumer safety considering the epidemiological link between street foods and food borne diseases. Strategies for improving street food safety can only be developed after appropriate studies and other information on local foods, conditions and practices will be obtained. However, in Ozamiz City, studies on street-vended foods were limited. This study was conducted to assess the microbial quality of streetvended foods and analyze factors that could predispose foods to contamination as part of the major concerns of public health, and a focus for the City Health Office (CHO) to raise public awareness. 


\section{Materials and Methods}

\section{Data Gathering Procedure}

Prior to starting the investigation, the research team asked approval from the $\mathrm{CHO}$ and explained the aim of the study. The street food vendors were included in the study after the $\mathrm{CHO}$ gave their approval and they were assured total confidentiality. The purpose of the study was explained to the individual vendors involved. A structured questionnaire was used to gather the necessary data on the profile of the vendors, personal hygiene, food handling practices and care of equipment. Vendors were interviewed using a questionnaire that was translated into Cebuano.

\section{Study Population and Sample Collection}

There were approximately eight vending sites namely: Ozamiz City National High School, three tertiary educational institutions (MU, Medina College and LSU), three major streets (Rizal Avenue, Juan Luna, Zamora) and Ozamiz City Central School. They are among the busiest street-vended foods in Ozamiz City (Figure 1). The people in charge of the vending points (subsequently referred to as the vendors) were the main subjects of the study. A total of 110 vendors from a random selection were included in the study. Food items (cooked/uncooked) prepared and/ or sold by 41 ambulant, and 69 stationary vendors were collected for microbial analysis. The ambulant incorporates the so-called semi-static vending unit in which the selling unit is removed after a relatively long period of selling.

Samples of about $50 \mathrm{~g}$ of each food on sale were placed in separate sterile containers and transported to the laboratory immediately right after collection. 


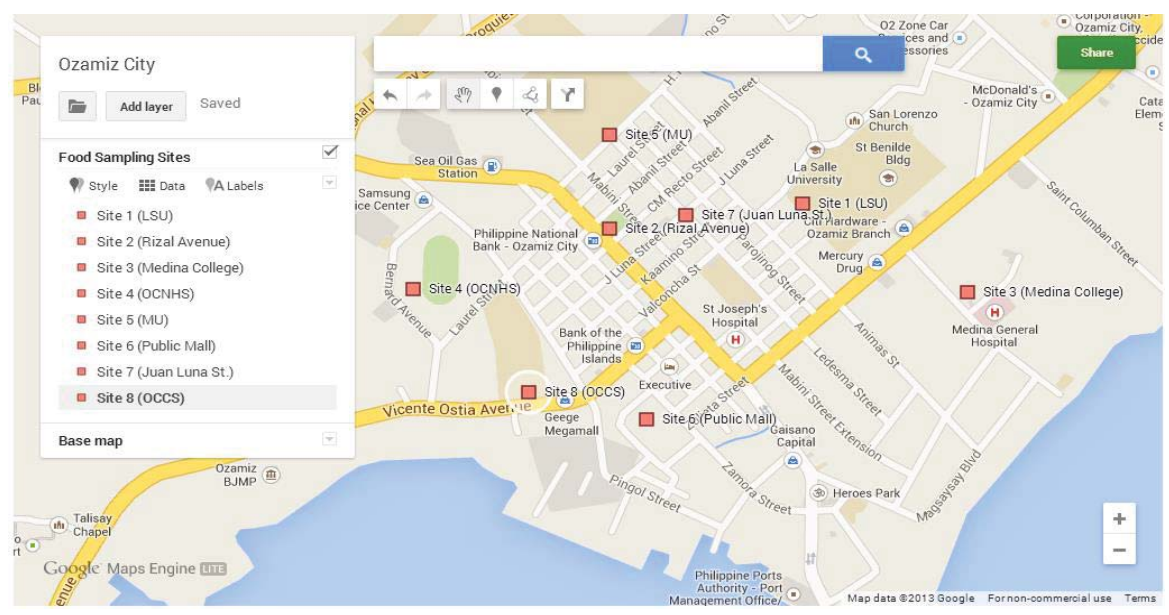

Figure 1. Street-vended food sampling sites in Ozamiz City, Philippines.

\section{Microbial Analysis of Street Food}

Microbiological analysis was performed in Misamis University, Natural Science Laboratory. Identification of microorganisms was limited to its possible taxonomic classification.

Standard microbiological methods were used, according to South African Bureau of Standards (SABS) ISO methods with some modifications. Summaries and modifications of the methods follow:

\section{Total Aerobic Plate Count and Identification of Bacteria}

The total aerobic plate count is intended to indicate the level of microorganisms in a product. Portions of food weighing $10 \mathrm{~g}$ were diluted at 1:10 with $90 \mathrm{ml}$ peptone water and placed in a Stomacher for 2 minutes. Further tenfold serial dilution was made and examined by means of the pour plate method. All dilutions were plated, using Plate Count Agar (PCA), according to SABS ISO method 4833:1991 (Martins \& Anelich, 2000a). The plates were incubated at $35^{\circ} \mathrm{C}$ for 48 hours, and duplicate plates containing between 30 and 300 colonies were counted. Average counts obtained were expressed as colony forming units per gram of food ( $\mathrm{cfu} / \mathrm{g}$ ) by multiplying the number of bacteria by the dilution. 


\section{Staphylococcus aureus}

Gram staining procedure was used to describe bacterial morphology. Staphylococci are spherical Gram-positive bacteria that occur in microscopic clusters (Todar, 2012). S. aureus forms a fairly large yellow colony on rich medium while $S$. epidermidis has a relatively small white colony (Todar, 2012). Staphylococcus aureus, '(staph)', is a bacterium commonly found on the hands, mouth, skin, or nose of food handlers.

\section{Escherichia coli}

Coliforms are Gram-negative rods that produce acid and gas from lactose during metabolic fermentation. The coliform group includes species from the genera Citrobacter, Klebsiella, Enterobacter, and E.coli. E. Coli can be differentiated from most other coliforms by its ability to ferment lactose in the fecal coliform test, and by its growth and color reaction on certain types of culture media (Siegrist, 2013). Presumptive, Confirmatory, and Completion tests were done successively to determine $E$. Coli following the standard methods.

In Presumptive test, each set of volume $(10 \mu \mathrm{L} ; 100 \mu \mathrm{L} ; 1000$ $\mu \mathrm{L})$ of the food samples was inoculated into three large test tubes each containing lactose broth and inverted Durham tube. The tubes were incubated for 24 hours at $37^{\circ} \mathrm{C}$. The presence of air in each of the Durham tubes indicated a positive result for coliform contamination. A confirmatory test was done for samples that showed positive results using Brilliant Green Lactose Bile Broth (BGLB) inverted in Durham tube. Samples that showed positive results in Confirmatory test were inoculated in the Eosin Methylene Blue (EMB) agar plates for Completion test using the streak plating technique. The plates were incubated for 48 hours at $37^{\circ} \mathrm{C}$. The presence of colonies with greenmetallic sheen indicated the presence of $E$ coli.

\section{Data Analysis}

The data was systematically organized and analyzed using EpiInfo version 6 software. It is a public domain statistical software for epidemiology that allows for data entry and analysis. The values that were obtained for $\mathrm{cfu} / \mathrm{g}$ of food were transformed into $\log _{10}$ values. Foods were classified as having no-to-low risk of transmitting pathogenic bacteria if the total count is less than $5.0 \log _{10} \mathrm{cfu} / \mathrm{g}$. A 
classification of medium-to-high risk corresponded to values of at least $5.0 \log _{10} \mathrm{cfu} / \mathrm{g}$ for total.

\section{Results and Discussion}

\section{Profile of street food vendors and hygiene practices}

Both men and women were involved in street-food vending and whether men or the women dominated the trade, vary from one country to another. In this study, it revealed that street food trade in Ozamiz city was conducted by both males (38.2\%) and females $(61.8 \%)$ (Table 1). Although most of the vendors were women, it was found out that men and women divided their tasks and responsibilities. Women cooked the food to be sold later in the day while the men were responsible for buying all that was necessary for preparation of the food or vice versa. Similar results were reported in other countries (e.g. Nigeria, Ghana, Uganda and Kenya, south Africa) including Botswana, in which the majority of vendors are women who balance the income-generating opportunities of street vending with traditional household and child care duties (Bobodu, 2010; Mwangi et al., 2002: Mensah et al., 2002: Martins \& Anelich, 2000b). In Mexico City (Muñoz de Chávez et al., 2000) division of labor was pronounced. Women worked an early shift in the stall, until about noon, when the men took over and stayed late. Men were responsible for cleaning the stalls and the cooking equipment in the stall while women washed the utensils and dishes at home.

In this study, the age range of vendors was between $\leq 20 \quad-70$ years with a majority being in the age group of 20-29 (39.1\%) and $30-39(26.4 \%)$ respectively. Bhat and Waghray (2000) reported that the average age of the vendors in Asian countries was 20-45 years. Most of the vendors $(60.9 \%)$ had a secondary school qualification, but $7(6.4 \%)$ had no formal schooling nevertheless; they exhibited good hygiene behavior as indicated by the high prevalence of handwashing and personal care. 
Table 1. Profile of the street food vendors and personal hygiene.

\begin{tabular}{lc}
\hline \hline Parameter & Frequency $(\mathrm{n}=110)$ \\
\hline Age (years) & $15(15.5)^{\mathrm{a}}$ \\
$\leq 20$ & $43(39.1)$ \\
$20-29$ & $29(26.4)$ \\
$30-39$ & $8(07.3)$ \\
$40-49$ & $11(10.0)$ \\
$50-59$ & $2(01.8)$ \\
$60-69$ & \\
Sex & $68(61.8)$ \\
Female & $42(38.2)$ \\
Male & \\
Educational Attainment & $7(06.4)$ \\
None & $17(15.5)$ \\
Primary school & $67(60.9)$ \\
Secondary school & $8(07.3)$ \\
Diploma/certificate & $8(07.3)$ \\
Tertiary & $3(02.7)$ \\
College Graduate & \\
Personal hygiene & $59(53.6)$ \\
Hands washed at least three times daily & $48(43.6)$ \\
Hands washed more than three times daily & $3(02.7)$ \\
Hands were not washed throughout the day & $77(70.0)$ \\
Clean clothes & $67(60.9)$ \\
Fingernails cut & $12(10.9)$ \\
Hair covered &
\end{tabular}

${ }^{\mathrm{a}}$ Figures in parentheses are percentages.

\section{Vending operation and vending site hygiene}

There were two major types of vending units involved in this study: the ambulant (37.3\%) and the fixed or static $(62.7 \%)$ vending unit (Table 2). In ambulant vending unit, the vendor does not have fixed premises but moves from one location to another. The stationary or fixed vending unit is permanently located. The major advantage of being mobile is accessibility to the buyer. This advantage makes the mobile vendor less dependent on location. However results showed that fixed or stationary vending units tend to be higher than the operation of their ambulant counterpart. This might be because mobility limits the amount of food that is carried due to the weight of goods and the majority of the vendors were female. Similar results were reported in Ghana (Mensah et al., 2002), 
Singapore (Acho-chi, 2002) and Dhaka (Muzaffar, 2009) in which most of the vending units were stationary.

Table 2. Characteristics of vending operation and site hygiene.

\begin{tabular}{ll}
\hline \hline Parameter & $\mathbf{n}$ \\
\hline Type of Vendor & \\
Ambulant & $41(37.3)^{\mathrm{a}}$ \\
Stationary & $69(62.7)$ \\
Type of vending site & $5(04.6)$ \\
Chop bar (protected) & $80(72.7)$ \\
Open air & $25(22.7)$ \\
Schools & \\
Proximity of the vending area & $67(60.9)$ \\
Drainage & $10(09.1)$ \\
Sewerage & $10(09.1)$ \\
Manhole & $10(09.1)$ \\
Dustbin & $3(02.7)$ \\
Toilet & $10(09.1)$ \\
Others (specify)near $\quad$ seawall, & \\
Vending site hygiene & $7(06.4)$ \\
Much litter & $49(44.5)$ \\
Some litter & $19(17.3)$ \\
No litter & $22(20.0)$ \\
Litter bin available & $13(11.8)$ \\
Stagnant water on ground & \\
\hline \hline
\end{tabular}

${ }^{a}$ Figures in parentheses are percentages.

People bought street foods held in open or protected structures. Although $60.9 \%$ of the vending areas were near drainage, only seven $(6.4 \%)$ were classified as very dirty. In the Philippines, the government took a decision to legalize street vending and decided to issue the vendors with identity cards and allow them to ply their trade in certain areas (Vanzi, 2001). A memorandum of understanding (MoU) was signed by the department of interior and local government, department of labor, department of trade and industry and the league of provinces. The MoU mentions that the vendors' associations would be encouraged to take on the responsibility of regulating street vendors by ensuring cleanliness on the streets and proper hygiene (Bhowmik, 2005). The present study identified a number of factors that could reduce the risk of contamination. An example was the sale of food in chop-bars. These were usually wooden structures, which may be completely or partially enclosed. 112 
There was an area for food preparation and most foods sold in these facilities are freshly prepared or reheated. It was observed that food sold in schools near drainage without covering carried the highest risk of transmitting bacteria. A study on foods sold in Bangladesh schools showed unacceptable levels of bacteria (Al Mamun et al., 2013).

\section{Food Handling Practices and Care of Equipment}

Food-handling practices that could affect the microbial quality of street foods are indicated in Table 3. Fifty-five (55\%) of the 110 vendors cooked food on morning sale, 17.3\% cooked food while cooking, and $32.7 \%$ cooked food well in advance of consumption. Seventy-seven percent $(77 \%)$ served food with spoon, fork or stick, and $48.18 \%$ served food into a cup or plate. However, a considerable percentage $(73.6 \%)$ served food with bare hands and $46.36 \%$ of the foods were exposed to flies. Most of the vendors used clean water in washing of crockery $(68 \%)$. It was found out that the use of a fork or spoon to serve food reduced the level of contamination while the use of bare hands resulted in an increase. Vendors were carriers of a variety of bacterial enteropathogens (Mensah et al., 2002). Poor personal hygiene can facilitate the transmission of these pathogens via food to humans. The serving stage is a critical point in the street food industry. Enteropathogens can survive on the hands for three hours or longer (Mensah et al., 2002). E. coli was detected in hand washings of high-income and low-income mothers in India at levels of 7.0 $+4.2 \log 10 \mathrm{cfu} / \mathrm{ml}$, and $9.0+5.7 \log 10 \mathrm{cfu} / \mathrm{ml}$, respectively (Marthur \& Reddy, 1983).

\section{Microbiological Analysis}

A total of 173 menu items, classified as snack foods, main dishes, sauces, and cold dishes (Figure 2) were examined for the presence of $S$. aureus and E. coli, and the total aerobic plate count (TAPC). Most foods were within acceptable limits, i.e. $<5.0 \log 10 \mathrm{cfu} / \mathrm{g}$ for total counts. Of the 173 food samples, $104(60.1 \%)$ contained S. aureus and $69(39.9 \%)$ detected with E. coli (Table 4). A large proportion of main dishes (rice, boiled pickled fish with vegetable, mix vegetables with coconut milk, braised pork belly, spicy chicken with coconut milk) were the least contaminated with $<5.0 \log 10 \mathrm{cfu} / \mathrm{g}$ for total counts. There were few $S$. aureus detected in some of the samples and no E. coli in any of these 
foods. Boiled pickled fish with vegetable (fish paksiw) is a saltwater fish cooked with vinegar or lemon juice, garlic, onions with little or no oil and as little water. This traditional food preparation technology produces an environment that inhibits various diarrheal pathogens. The contamination of this food possibly occurred during serving. Rice and mix vegetables with coconut milk were prepared by boiling, a temperature range that kills most bacteria, and was served hot, a factor accounting for the relatively low levels of bacteria in this product. If care is taken during serving, microbial quality can be markedly improved (Manguiat \& Fang, 2013). The scooping of rice and mixed vegetables with coconut milk into bowls or polythene bags might be the influence in the contamination of these foods.

\section{Table 3. Food handling practices and care of equipment.}

\begin{tabular}{ll}
\hline \hline Parameter & $\mathrm{n}$ \\
\hline Food handling practices & \\
Food cooked well in advance of consumption & $36(32.7)^{\mathrm{a}}$ \\
Food cooked on the morning of sale & $55(50.0)$ \\
Food cooked during sale & $19(17.3)$ \\
Cooked food sold from a cooking pot & $25(22.7)$ \\
Cooked food scooped into bowls or polythene bags & $50(45.5)$ \\
Food sold from mesh protection & $28(25.5)$ \\
Food kept on cooking fire during sale & $29(26.4)$ \\
Food sold from the tray with covering & $67(60.9)$ \\
Food sold from the tray with no covering & $33(30.0)$ \\
Food reheated before sale & $27(24.6)$ \\
Food exposed to flies & $51(46.4)$ \\
Food handled at ground level & $13(11.8)$ \\
Serving of food & \\
Food served with fork/spoon/stick & $77(70.0)$ \\
Food served with bare hands & $81(73.6)$ \\
Food served into cup/plate & $53(48.2)$ \\
Food served into paper/leaves/plastic & $47(42.7)$ \\
Cleaning of crockery & \\
Water with soapy appearance & $17(15.5)$ \\
No soap used & $5(04.6)$ \\
Water with oily appearance & $13(11.8)$ \\
Water with dirty appearance & $7(06.4)$ \\
Clean water used & $68(61.8)$ \\
\hline \hline
\end{tabular}

${ }^{a}$ Figures in parentheses are percentages. 


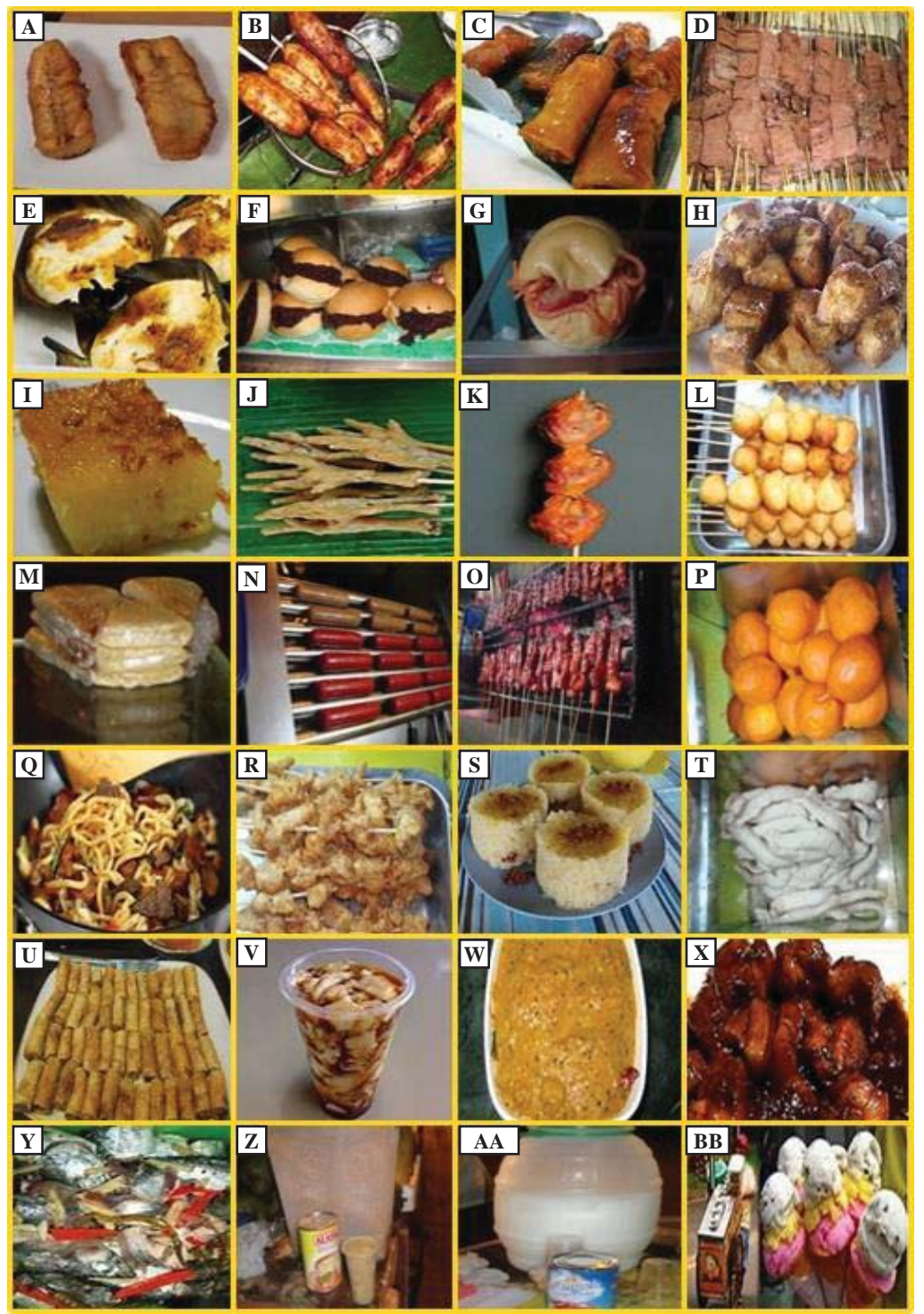

Figure 2. Images of street-vended foods encountered in the study.
A. Banana coated with flour
H. Camote cue
O. Isaw \& Pork barbecue
V. Taho
B. Banana cue
P. Boiled egg coated with flour
W. Ground banana coconut cake
C. Banana turon
Q. Pansitw/ pork
J. Chicken feet (Adidas)
K. Chicken head
R. Dried chicken Skin
X. Braised pork belly (humba)
D. Betamax
L. Fishball
S. Steamed cassava cake
Y. Boiled pickled fish
E. Rice cake (Bibingka)
F. Sticky Rice Cake (Biko)
M. Hotcake
Z. Fruit Salad
AA. Buko Juice
N. Hotdog
T. Tempura
U. Lumpia
BB. Ice cream 
Table 4. Total bacterial counts [Mean $\log _{10} \mathrm{cfu} / \mathrm{g}(\mathrm{ml}) \pm$ standard deviation for foods with at least 3 samples \& $\log _{10} \mathrm{cfu} / \mathrm{g}(\mathrm{ml})$ for 1 food sample] and Presence of $S$. aureus and $E$. coli in street-vended foods, Ozamiz City.

\begin{tabular}{|c|c|c|c|c|}
\hline Food Item & $\mathrm{n}$ & total counts & S. aureus & E.coli \\
\hline \multicolumn{5}{|l|}{ SNACK FOODS } \\
\hline Banana coated with flour & 3 & $4.4 \pm 0.32$ & $+(3)$ & $+(1)^{\mathrm{a}}$ \\
\hline Banana cue & 5 & $4.6 \pm 0.75$ & $+(3)$ & $+(3)$ \\
\hline $\begin{array}{l}\text { Boiled egg coated with flour } \\
(k w e k-k w e k)\end{array}$ & 5 & $4.3 \pm 0.19$ & $+(2)$ & \\
\hline Burger bun with spaghetti & 6 & $6.1 \pm 0.63$ & $+(4)$ & $+(4)$ \\
\hline Butchi & 3 & $4.5 \pm 0.62$ & $+(1)$ & $+(1)$ \\
\hline Camote cue & 3 & $4.6 \pm 0.66$ & $+(1)$ & $+(1)$ \\
\hline Cassava cake & 3 & $4.8 \pm 0.43$ & $+(2)$ & $+(2)$ \\
\hline Chicken feet (Adidas) & 6 & $4.9 \pm 1.06$ & $+(6)$ & $+(4)$ \\
\hline Chicken head (helmet) & 6 & $4.9 \pm 0.23$ & $+(2)$ & $+(3)$ \\
\hline Chicken intestine (isaw) & 7 & $4.4 \pm 1.00$ & $+(2)$ & $+(2)$ \\
\hline $\begin{array}{l}\text { Deep fried lumpia wrapped banana } \\
\text { (turon) }\end{array}$ & 5 & $4.4 \pm 0.69$ & $+(3)$ & $+(2)$ \\
\hline $\begin{array}{l}\text { Dried cassava with sticky coconut } \\
\text { milk tappings (keping) }\end{array}$ & 3 & $4.3 \pm 0.09$ & $+(3)$ & \\
\hline Dried chicken skin (proben) & 3 & $4.2 \pm 0.21$ & $+(1)$ & \\
\hline Fishball & 7 & $5.1 \pm 1.25$ & $+(5)$ & $+(4)$ \\
\hline Hotcake & 3 & $3.9 \pm 0.86$ & $+(1)$ & $+(1)$ \\
\hline Hotdog & 5 & $4.9 \pm 1.33$ & $+(3)$ & $+(2)$ \\
\hline Pansit behon with pork & 3 & $6.0 \pm 1.10$ & $+(1)$ & $+(3)$ \\
\hline $\begin{array}{l}\text { Pig's blood or dried chicken blood } \\
\text { (betamax) }\end{array}$ & 5 & $5.0 \pm 2.58$ & $+(5)$ & $+(3)$ \\
\hline Popcorn & 5 & $5.4 \pm 1.20$ & $+(2)$ & $+(5)$ \\
\hline Pork barbecue & 6 & $4.0 \pm 0.23$ & $+(3)$ & $+(4)$ \\
\hline Rice cake (bibingka) & 3 & $4.4 \pm 0.56$ & $+(2)$ & $+(1)$ \\
\hline Sticky rice cake (biko) & 3 & $4.3 \pm 0.09$ & $+(1)$ & $+(2)$ \\
\hline Steamed cassava cake (puto cassava) & 3 & $4.8 \pm 1.16$ & $+(1)$ & $+(1)$ \\
\hline Siomai & 3 & $4.7 \pm 1.83$ & $+(2)$ & $+(1)$ \\
\hline Tempura & 4 & $5.7 \pm 1.09$ & $+(4)$ & $+(3)$ \\
\hline Banana cupcake & 1 & 4.100371 & + & \\
\hline Cheese Stick & 1 & 4.460898 & + & \\
\hline Chicken lumpia & 1 & 4.158362 & + & \\
\hline Lumpia shanghai w/ veg. & 1 & 4.31597 & + & \\
\hline Ground banana coconut cake (luyang) & 1 & 3.982898 & + & \\
\hline Salted peanut & 1 & 4.049218 & & \\
\hline Soy/beancurd pudding (taho) & 1 & 4.152288 & + & \\
\hline MAIN DISHES & & & & \\
\hline Boiled pickled fih (fish paksiw) & 3 & $3.8 \pm 0.72$ & & \\
\hline
\end{tabular}


Table 4 continued: Total bacterial counts [Mean $\log _{10} \mathrm{cfu} / \mathrm{g}(\mathrm{ml}) \pm$ standard deviation for foods with at least 3 samples $\& \log _{10} \mathrm{cfu} / \mathrm{g}(\mathrm{ml})$ for 1 food sample] and Presence of $S$. aureus and $E$. coli in street-vended foods, Ozamiz City.

\begin{tabular}{lrrrr}
\hline \multicolumn{1}{c}{ Food Item } & $\mathrm{n}$ & Total counts & S. aureus & E.coli \\
\hline Braised pork belly (pork humba) & 3 & $4.1 \pm 0.12$ & $+(3)$ & \\
Mix vegetable with coconut milk & 3 & $3.9 \pm 0.44$ & $+(1)$ & \\
Pork blood stew (dinuguan) & 3 & $4.1 \pm 0.14$ & $+(1)$ & \\
Rice & 5 & $3.5 \pm 0.21$ & $+(2)$ & \\
Spicy chicken with coconut milk & 3 & $4.1 \pm 0.66$ & & \\
(halang-halang) & & & & \\
SAUCES \& COLD DISHES & & & $+(9)$ & $+(8)$ \\
Coconut milk drink (buko juice) & 10 & $7.1 \pm 1.63$ & $+(2)$ & $+(1)$ \\
ice cream & 5 & $4.1 \pm 0.25$ & $+(9)$ & $+(7)$ \\
Fruit salad & 9 & $7.0 \pm 2.06$ & $+(4)$ & $+(2)$ \\
Shake & 6 & $4.1 \pm 0.83$ & $+(3)$ & $+(2)$ \\
Sauces & 5 & $3.8 \pm 0.45$ & & $+(104$ or \\
$\quad$ TOTAL & 173 & & $60.1 \%)$ & $+(69$ or \\
& & & & \\
& & & & \\
\hline \hline
\end{tabular}

${ }^{a} \overline{\text { Figures in parentheses are a number of food samples that showed a positive result. }}$

Considerable items of snacks foods were contaminated with unacceptable levels of bacteria classified as medium-to-high risk corresponded to values of at least $5.0 \log 10 \mathrm{cfu} / \mathrm{g}$ for total counts. Majority of the foods showed positive results for $S$. aureus and E. coli (Figure 3). These foods were burger bun with spaghetti, pansit behon with pork, fishball, tempura, and popcorn. The preparation of burger bun with spaghetti involved steaming and placed in polythene bags with bare hands. Pansit behon with pork was prepared by frying the mix behon and pork then served in a platter/bowl with a spoon or fork. It was observed that these foods were cooked well in advance of consumption. Time and temperature abuse are said to be the major factors that contribute to foodborne disease (Rane, 2011; Harrington, 2010; Shimoni et al., 2006; Bhowmik, 2005). In the Philippines, it was established that meatcontaining dishes were the common causes of the outbreaks, with spaghetti as the leading food vehicle (Azanza, 2006). Similar results were reported in OZFOODNET (2011). The consumption of pansit (rice noodles with shrimps, meat and vegetables), a similar street food, has been associated with cholera in Manila (Lim-Quizon et al., 1994). In 2000, Godoy reported food poisoning outbreak due to the consumption of spaghetti a la carbonara caused by Salmonella enteritidis. 


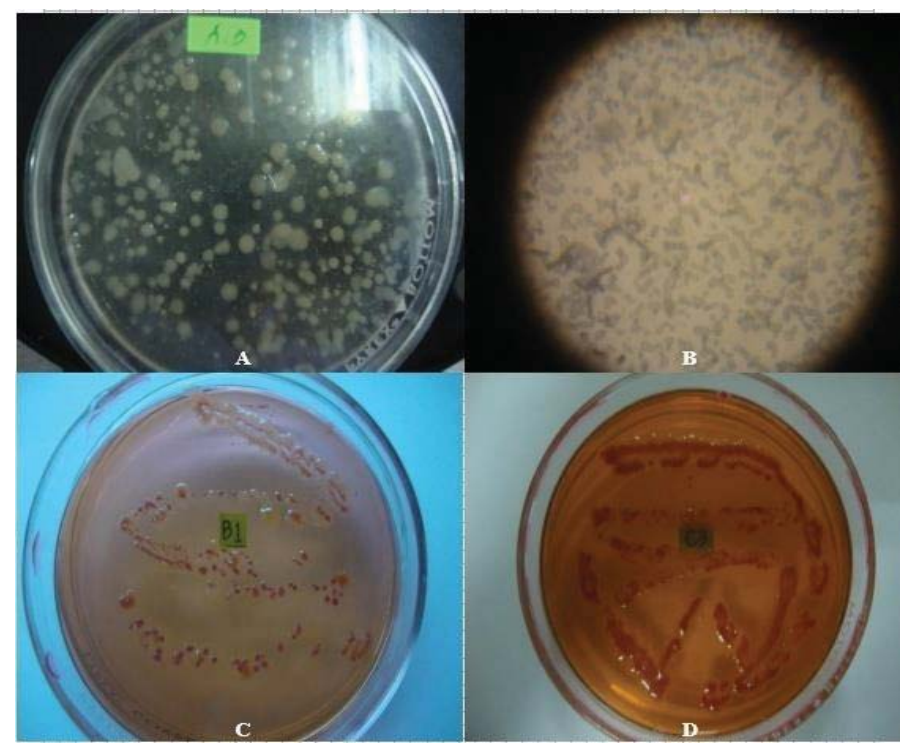

Figure 3. Images of microbes observed in street-vended foods. $(A=$ used in total aerobic plate count; $B=$ gram-staining result; $C \& D=E M B$ Completion test for $E$. coli results)

Both fishball and tempura were prepared by deep-frying and served in a tempura rack or in a plate, stick or foil box. Popcorn is a corn in which the kernel when exposed to heat are exploded into large fluffy masses after frying packaging was done in a plastic or cellophane with bare hands. Hygiene during handling and cooking of street foods was observed. It was noticed that vendors who sold these snacks did not wash their hands because they did not have enough water. None of the vendors and the assistants did practice good personal hygiene; gloves, uniforms, and aprons were not in use and only few of them cover their hair $(10.9 \%)$. This might be an indication of potential contamination during serving of the cooked food by the vendors, or cross-contamination by working surfaces and/or utensils. Hanashiro et al. (2005) in Sao Paulo city, Brazil and Faruque et al., (2010) in Bangladesh examined microbiological quality of selected street foods and observed that personal hygiene of vendors during handling and cooking is very important as it causes serious health hazards to the consumers.

Coconut milk drink (buko juice) and fruit salads carried the greatest risk of transmitting pathogens. In general, bacterial counts 
were high with a total mean $\log 10$ of 7.1 and 7.0 respectively. These foods were vastly contaminated with $S$. aureus and E. coli. The high levels of contaminants in buko juice and salads were expected. These foods were prepared in advance of consumption and served using bare hands in a plastic cup or glass with a straw. It was also observed that vendors often talked while serving the foods. Moreover, milk and water were part of the ingredients of these foods. Milk is one of the most versatile ingredients among cooks and a staple in most households. However, as an animal product that is full of nutrients, there are several infectious diseases associated with microbecontaminated milk and milk products (Koo, 2008). E. coli can also be found in contaminated water and milk (Crawford, 2010). These findings call for a careful analysis before the preparation and sale of these street foods.

\section{Conclusion and Recommendations}

The findings indicate that street food vendors in Ozamiz City practiced minimal hygienic and sanitary practices. The hygienic practices in question included personal hygiene, food preparation, handling practices and care of equipment. A large proportion of main dishes (rice, boiled pickled fish, mix vegetables with coconut milk, braised pork belly, spicy chicken with coconut milk) were the least contaminated but samples of cold dishes (coconut milk drink, fruit salads) had unacceptable levels of contamination. This study recommends that every vendor, helper or food handler has to undergo proper training with regard to basic food hygiene, knowledge of preservation, storage of food, lapse time between preparation and dispensing of food items to the consumers. This is to ensure that they follow the required rules of food safety, hygiene practices and sanitation. The government has to invest in the street food industry as it provides employment, cheap food, and a wide variety of foods for the urban dwellers. There is a need for stricter implementation of the food sanitation code, licensing of street food vendors and issuing health cards. In order to maintain the benefits of street-vended food system while assuring the safety of the food sold authorities need to develop a policy aimed at assisting, controlling and maintaining the street food sector. The policy developed has to respond to an integrated 
consultation with vendors and consumers if it is to meet the needs of each of the partners in food safety (government, consumers and vendors).

There is a need for further study on foods classified as medium to high risk that include the total counts of coliform, S. aureus, E. coli, $B$. cereus, Salmonella and other food-borne microorganisms. Determinations of these types of bacteria act as a quick index of acceptability of food for human consumption.

\section{Acknowledgment}

The authors would like to thank Misamis University, Ozamiz City for the research fund.

\section{Literature Cited}

Acho-Chi, C. (2002). The mobile street food service practice in the urban economy of Kumba, Cameroon. Singapore Journal of Tropical Geography, 23 (2), 131-148.

Al Mamun, M., Rahman, S. M., \& Turin, T. C., (2013). Microbiological quality of selected street food items vended by school-based street food vendors in Dhaka, Bangladesh. International Journal of Food Microbiology, 166(3), 413-8. doi: 10.1016/j. ijfoodmicro.08.007.

Azanza, M. P. V. (2006). Phillipine foodborne-disease outbreaks (1995-2004). Journal of food safety, 26(1), 92-102.

Bhat, R.V. \& Waghray, K. (2000). Profile of street foods sold in Asian countries. World Rev. Nutr. Diet., 86, 53-99. doi: 10.1159/00005 9731.

Bhowmik, S.K. (2005, May 28-June 4). Street Vendors in Asia. A Review Economic and Political Weekly, p.2257-64.

Bobodu, D. E. (2010). Small scale business: A case study of stagnation amongst street food vendors in Accra. Retrieved from http://air. ashesi.edu.gh/ handle/123456789/28 
CAREC (2002). Reported cases of communicable diseases for CAREC member countries - A quarterly review of selected diseases - Weeks 40-52 of 2001. Caribbean Epidemiology Centre Communicable Disease Feedback Report. 6 (4), 1-9.

Cho, K., Park, S. \& Joo, N. (2011). Study on a model of street vended food choices by Korean high school students. Nutrition Research and Practice, 5(5), 481-488. doi: 10.4162/nrp.2011.5.5.481

Crawford, N. (2010). What Microbes Cause Food Poisoning? The National Center for Biotechnology Information.

Dardano, C. (2003). Caribbean regional working group on street food vendors. Report of FAO, PAHO and BNSI. Retrieved from $\mathrm{ftp}: / / \mathrm{ftp}$. fao.org/es/esn/food/carribean_report.pdf

Donkor, E. S. (2009). Application of the WHO five keys of food safety to improve food handling practices of food vendors in a poor resource community in Ghana. East African journal of public health, 6(2), 148-51

Faruque, Q., Haque, Q. F., Shekhar, H. U., \& Begum, S. (2010). Institutionalization of healthy street food system in Bangladesh: A pilot study with three wards of Dhaka city corporation as model. National food policy capacity strengthening programme. Final report $\mathrm{PR} \# 7 / 07$

Godoy, P., Artigues, A., Usera, M. A., Gonzalez, J. L., Pablo, N., \& Agusti, M. (2000). Food poisoning outbreak due to the consumption of spaghetti a la carbonara caused by Salmonella enteritidis. Enfermedades infecciosas y microbiología clínica, 18(6), 257-61.

Grifffiths, M.W. (2002). Fighting food safety problems. In N. H. Mermelstein (Ed.). Food Research trends - 2003 and Beyond Food Technology, 56 (12), 30-49. 
Halton Region Health Department. (2001). Food Safety Program. Regional Municipality of Halton, Ontario, Canada. Retrieved from http:www.region.halton.on.ca/health/programs/foodsafety/fdsafetyl ist.htm.

Hanashiro, A., Morita, M., Matte, G. R., Matte, M. H., \& Torres, E. A. F. S. (2005). Microbiological quality of selected street foods from a restricted area of Sao Paulo city, Brazil. Food Control, 16, 439444.

Harrington, R. (2010, September 24). Temperature abuse of packaged salads raises food safety fears-a study. Food Production daily.com. Retrieved from http://www.foodproductiondaily.com/SafetyRegula tion/Temperature-abuse-of-packaged-salads-raises-foodsafety-fears-study

Koo, I. (2008, Nov. 21). Got Milk Microbes? A Guide to Milk-borne Infectious Diseases. About.com. Retrieved from http://infectious diseases.about.com/bio/Ingrid-Koo-Ph-D-50107.htm.

Lim-Quizon, M. C., Benabaye, R. M., White, F. M., Dayrit, M. M., \& White, M. E. (1994). Cholera in metropolitan Manila: foodborne transmission via street vendors. Bulletin of the World Health Organization, 72(5), 745.

List of street foods - Wikipedia, the free encyclopedia. (n.d.).

Retrieved from http://en.wikipedia.org/wiki/Street_food_of_dhaka

Manguiat, L. S., \& Fang, T. J. (2013). Microbiological quality of chicken- and pork-based street-vended foods from Taichung, Taiwan, and Laguna, Philippines. Food Microbiology, 36(1), 5762. doi: 10.1016/j.fm.2013.04.005.

Martins, J. H., \& Anelich, L. E. (2000a). Improving Street Foods in South Africa. Docstoc.com. Retrieved from http://www.docstoc. com/docs/72287634/Improving-Street-Foods-in-South-Africa 
Martins, J. H., \& Anelich, L. E. (2000b). Socioeconomic and Hygiene Features of Street Food Vending in South Africa. Pretoria: Unisa, Bureau of Market Research, 5-7.

Martins, J. H. (2006). Socio-economic and hygiene features of street food vending in Gauteng. South African Journal of Clinical Nutrition, 19(1), 23-24.

Mathur, R., \& Reddy, V. (1983). Bacterial contamination of infant foods. Indian Journal of Medical Research, 77, 342-6.

Mensah, P., Manu, D. Y., Darko, K. O., \& Ablordey, A. (2002). Street foods in Accra, Ghana: how safe are they?. Bulletin of the World Health Organization, 80 (7), 546-554.

Miles, S., Braxton, D. S., \& Frewer, L. J. (1999). Public perceptions about microbiological hazards in food. British Food J., 101(10), 744- 762 .

Monterjc. (2013, June). Street Food-Term Paper. Retrieved from www.studymode. com/ essays/Street-Foods-1802701.html

Muñoz de Chávez, M., Chávez - Villasana, , A., Chávez - Muñoz, M. \& Eichin Vuskovic, I. (2000). Sale of street food in Latin America. The Mexican case: joy or jeopardy?. In A. P. Simopoulus \& R. V. Bhat (Eds.). Street Foods,(pp. 138- 154). Karger, Basel, Switzerland.

Muzaffar, A.T., (2009). Entrepreneurs of the streets: an analytical work on the street food vendors of Dhaka City. International Journal of Business and Management, 4(2), 1-9.

Mwangi, A. M., den Hartog, A. P., Mwadime, R. K. M., van Staveren, W. A., \& Foeken, D. W. J. (2002). 'Do street food vendors sell a sufficient variety of foods for a healthy diet? The case of Nairobi'. Food and Nutrition Bulletin, 23 (1), 48 - 56. 
Nirathon, N. (2006). Fighting Poverty from the Street: A Survey of Street Food Vendors in Bangkok. International Labour Organization, Informal Economy, Poverty and Employment Thailand series, Number 1. p 14-15.

OzFoodNet (2011 October 31). OzFoodNet Quarterly Report. The OzFoodNet Working Group. Retrieved from http://www.health.gov.au/internet/main/publishing.nsf/Content/cda -cdi 3603j.htm

Powell, D. (2010). Safe food from farm. Retrieved from http://barfblog.com/tags/powell/page/4/

Rane, S. (2011). Street Vended Food in Developing World: Hazard Analyses. Indian Journal of Microbiology, 51(1), 100-106. doi: 10.1007/s12088-011-0154-x.

Rheinländer, T., Olsen, M., Bakang, J. A., Takyi, H., Konradsen, F., \& Samuelsen, H. (2008). Keeping up appearances: perceptions of street food safety in urban Kumasi, Ghana. Journal of Urban Health, (6), 952-64. doi: 10.1007/s11524-008-9318-3.

Shimoni, E., Anderson, E. M., \& Labuza, T. P. (2006). Reliability of Time Temperature Indicators Under Temperature Abuse. Journal of Food Science, 66(9), 1337-1340. doi: 10.1111/j.1365-2621.

Siegrist, J. (2013). Differentiation of Escherichia coli from coliforms. AnalytiX (8), Article 5. Retrieved from www.sigmaaldrich.com.

Todar, K. (2012). Online Textbook of Bacteriology. Retrieved from www.textbookof bacteriology.net. p.1

Vanzi, S. J. (2001). 'Metro Manila Street Vendors to be Legalised', Philippines Headline News Online. Retrieved from http://www.seasite.niu.edu/vanzi 